\title{
Effect of Caulerpa taxifolia on the productivity of two Mediterranean macrophytes
}

\author{
Esther Ferrer*, Amelia Gómez Garreta, M. Antonia Ribera
}

Laboratori de Botànica, Facultat de Farmàcia, Universitat de Barcelona, Avda. Joan XXIII s/n, E-08028 Barcelona, Spain

\begin{abstract}
The possible effect of Caulerpa taxifolia (Vahl) C. Agardh on 2 Mediterranean macrophytes (Cystoseira barbata f. aurantia and Gracilaria bursa-pastoris) was studied. The experiments were carried out with seasonal periodicity. Productivity of $C$. barbata f. aurantia placed in contact with C. taxifolia was lower in spring and summer The resistance of $G$ bursa-pastoris to $C$. taxifolia appeared to be effective throughout the year. In the presence of $C$. taxifolia extracts, both species showed lower productivity, but C. barbata f. aurantia appeared to be more sensitive than $G$. bursapastoris. Productivity started to fall at lower concentrations in summer and autumn than in winter or spring, in agreement with the annual variability of the extracts' toxicity.
\end{abstract}

KEY WORDS: Caulerpa taxifolia Introduced species Competition Mediterranean Sea

\section{INTRODUCTION}

The introduction of the tropical alga Caulerpa taxifolia (Vahl) C. Agardh in the western Mediterranean (Meinesz \& Hesse 1991) and its rapid expansion along the coasts of France, Italy and Spain (Meinesz et al. 1994b, 1995) have led to a biological invasion, which could involve a change in the composition of the littoral communities. Several studies have been developed, within the framework of a Life Programme of the European Community, with the aim of determining the impact of the populations of $C$. taxifolia on the autochthonous species and communities.

The Mediterranean specimens of Caulerpa taxifolia have given rise to dense, almost monospecific fields, which can develop on all sorts of substrate, totally or partially displacing the local populations. A regression of the autochthonous algal flora is observed in the areas colonized by C. taxifolia (Boudouresque et al. 1992). In these areas the populations of photophilous algae of the sublittoral exhibit elimination or reduction of indigenous species (Verlaque \& Fritayre 1994). There is, consequently, strong competition for space and light between $C$. taxifolia and the other phytobenthic species.

·E-mail: agomez@farmacia.far.ub.es
Other factors may, however, favor the invading species. Most Caulerpales synthesize toxic terpenoid compounds (Patterson et al. 1984, Paul \& Fenical 1986, Meyer \& Paul 1992). Caulerpenyne is a main secondary metabolite of Caulerpa taxifolia; it is an acetylenic sesquiterpene, which is specific to Caulerpa, as described by Amico et al. (1978) for C. prolifera. It has recently been shown that the Mediterranean populations of $C$. taxifolia synthesize not only caulerpenyne, present in all species of Caulerpa, but also other potentially toxic terpenes, described in these plants for the first time: Taxifolial A, Taxifolial B, Taxifolial C, 10, 11 epoxycaulerpenyne and the monoterpene Taxifolial D (Guerriero et al. 1992, 1993). Some of these compounds could be products of degradation or a precursor of caulerpenyne (Guerriero et al. 1992).

Several authors have demonstrated that the toxic compounds of Caulerpa taxifolia could be released into the surrounding water (Cuny et al. 1994, Giannotti et al. 1994, Merino et al. 1994, 1995, 1996). This assumption is inferred from the behavior of some organisms in contact with $C$. taxifolia both in natural populations and in laboratory cultures.

The aim of this study is to determine whether the toxicity of Caulerpa taxifolia could have a negative effect on Mediterranean phytobenthos. The species tested were 1 Phaeophyceae, Cystoseira barbata 
(Goodenough \& Woodward) C. Agardh f. aurantia (Kützing) Giaccone, and 1 Rhodophyceae, Gracilaria bursa-pastoris (Gmelin) Silva, the same as used in preliminary studies (Ferrer et al. 1995a, b, 1996). We designed our experiment on controlled cultures in the laboratory so that the only variable was the presence of Caulerpa toxins in the water. We measured the variation in the productivity of the tested species in response to different levels of these toxic compounds.

\section{MATERIAL AND METHODS}

Since the toxic effect of Caulerpa taxifolia on the macrophytobenthos is difficult to distinguish from other competition effects in situ, the experiments were carried out in laboratory cultures. The tests were performed in February (winter), May (spring), August (summer) and November (autumn) 1994, as the level of toxic metabolites in C. taxifolia varies with the time of year (Lemée et al. 1993).

The taxa of the local algal flora tested were Cystoseira barbata f. aurantia and Gracilaria bursa-pastoris, collected seasonally in the Bay of Els Alfacs (Delta de L'Ebre, Spain) between 0.5 and $2 \mathrm{~m}$ depth. These taxa do not occur naturally with Caulerpa taxifolia in the Bay of Els Alfacs at the moment, although the environmental characteristics of this closed bay could permit the development of $C$. taxifolia, as has happened in other sites of the Mediterranean Sea. In spite of this, these taxa were chosen because they can be easily cultured in laboratory since they are free-living plants. Specimens of the 2 taxa tested were harvested a few days before the beginning of the experiments and allowed to acclimatize to the aquarium environment.

Two independent series of experiments were performed in the laboratory to assess (1) the direct effect of the presence of Caulerpa taxifolia on the 2 macrophytes mentioned above and (2) the effect of methanol extracts from $C$. taxifolia on these taxa. Both experiments were carried out simultaneously and, as mentioned above, with seasonal periodicity.

In the first seasonal series of experiments, monospecific cultures (alga tested alone) were used as controls, and mixed cultures (alga tested with Caulerpa taxifolia) were used to test the potential toxicity of this species. Specimens of C. taxifolia were collected seasonally off Cap Martin (France), at $10 \mathrm{~m}$ depth, and they were transported to the laboratory in oxygenated, thermally isolated drums. The cultures were kept in $40 \mathrm{I}$ aquaria with natural sea water filtered through a Millipore membrane $(0.22 \mu \mathrm{m}$ pore size $)$ and renewed each week. In the mixed cultures, the biomass of $C$. taxifolia for aquarium was $250 \mathrm{~g}$ fresh weight and the ratio of the biomass of this species to that of the taxon tested was 2:1.
In the second seasonal series of experiments methanol extracts of Caulerpa taxifolia were used instead of the whole plant. These extracts were obtained by $\mathrm{R}$. Lemée and P. Amade (Université de Nice-Sophia Antipolis, France) from samples of this species collected seasonally off Cap Martin, at $10 \mathrm{~m}$ depth. To obtain these extracts the whole plant (fronds, stolons and rhizoids) was introduced into a methanol solution which, once filtered, was subjected to a vacuum drying process to be subsequently recovered in ethanol (Lemée et al. 1993). The resulting solution was stored at $-40^{\circ} \mathrm{C}$. The algae were tested seasonally with different concentrations of extracts corresponding to the same seasons (Table 1). As the toxicity of $C$. taxifolia is at a maximum in summer and autumn (Lemée et al. 1993) we tested lower concentrations in these 2 seasons. The dilutions necessary to obtain these different concentrations were obtained with ethanol since the methanol extract has a low solubility in water. For each taxon there was a control culture (in sea water) and cultures with the different concentrations of extract used (in sea water with extract). A control culture for the ethanol (in sea water with ethanol at the greatest concentration used in the dilutions) was carried out in the first experiment of this series (winter); as the results pointed out that the presence of ethanol in the water did not influence the productivity of the tested species, we did not repeat this control on the other seasons. The aquaria used for this series of experiments all had a capacity of $3 \mathrm{l}$, and the biomass of the alga tested in each one was around $25 \mathrm{~g}$ fresh weight.

All the experiments were carried out with an average irradiance of $150 \mu \mathrm{E} \mathrm{m} \mathrm{m}^{-2} \mathrm{~s}^{-1}$ and with a photoperiod of $12: 12 \mathrm{~h}$. The temperature of the water was set at $13,18,25$ and $18^{\circ} \mathrm{C}$, respectively, in winter, spring, summer and autumn, in order to reproduce the environmental conditions of the natural habitat.

The response of the tested species to the presence of Caulerpa taxifolia or its extracts was demonstrated by the variation in their productivity. Productivity was measured as the variation in the dissolved oxygen concentrations using the bottle incubation system (Littler 1979). Carbon productivity values were calculated from oxygen data using a photosynthetic quotient of 1 .

Table 1. Caulerpa taxifolia. Concentrations of extracts $\left(\mu \mathrm{g} \mathrm{ml}^{-1}\right)$ tested in the different seasons

\begin{tabular}{lccccccccc}
\hline & 5 & 10 & 15 & 30 & 60 & 125 & 250 & 500 \\
\hline Winter & & & & + & + & + & + & + \\
Spring & & & + & + & + & + & + & + \\
Summer & + & + & + & + & + & + & + & \\
Autumn & + & & + & + & + & + & & \\
\hline
\end{tabular}


Productivity of controls and treated Cystoseira barbata f. aurantia and Gracilaria bursa-pastoris was measured daily for $5 \mathrm{~d}$. After this period factors other than the Caulerpa effect begin to appear, which could modify the results. The first measure was carried out $12 \mathrm{~h}$ after putting the tested species in contact with Caulerpa taxifolia. Once a day 5 fragments (5 replicates) weighing $0.2 \mathrm{~g}$ were incubated from each culture, that is from the control cultures, the mixed cultures and the cultures with different concentrations of extract. The incubation irradiance was $300 \mu \mathrm{E} \mathrm{m}^{-2} \mathrm{~s}^{-1}$ and the time of incubation $1 \mathrm{~h}$.

The statistical treatment for both experiments corresponds to a Student's $t$-test, with a confidence interval greater than $95 \%$.

\section{RESULTS}

\section{Effect of Caulerpa taxifolia plants}

The effect of Caulerpa taxifolia on Cystoseira barbata f. aurantia depended on the season (Fig. 1). In spring and summer, the net productivity of the specimens of $C$. barbata f. aurantia placed in contact with the tropical alga
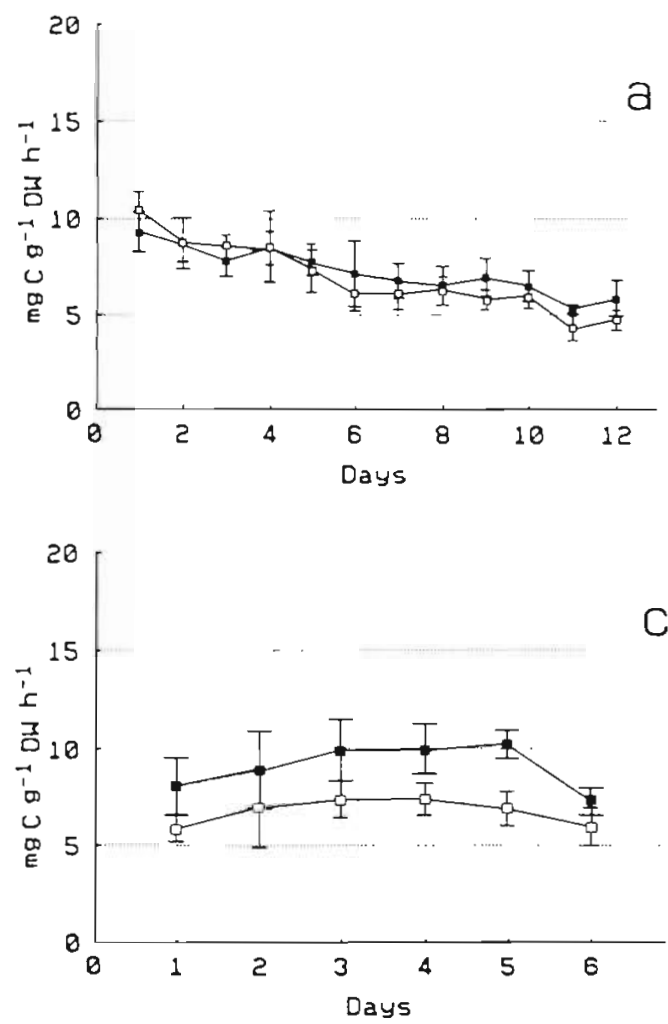

was significantly lower $(\alpha<0.05)$ than that of the monospecific culture specimens. The differences were greater in summer, when this reduction represented between 20 and $30 \%$ of the productivity of the controls. In autumn, despite a certain decline in the productivity of the alga in the presence of C. taxifolia, the differences were not significant. No effect was detected in winter.

Productivity of Gracilaria bursa-pastoris was not significantly affected by the presence of Caulerpa taxifolia in any season of the year (Fig. 2). A certain increase in the values corresponding to mixed cultures was observed in some cases, but these differences were not significant. The small differences detected in the winter samples were probably due to the morphological heterogeneity of the fragments.

\section{Effect of Caulerpa taxifolia extracts}

The response of Cystoseira barbata f. aurantia and Gracilaria bursa-pastoris, respectively, to the presence of methanol extracts of Caulerpa taxifolia in different seasons is shown in Figs. 3 \& 4 .

In winter the productivity of Cystoseira barbata f. aurantia significantly decreased in plants maintained
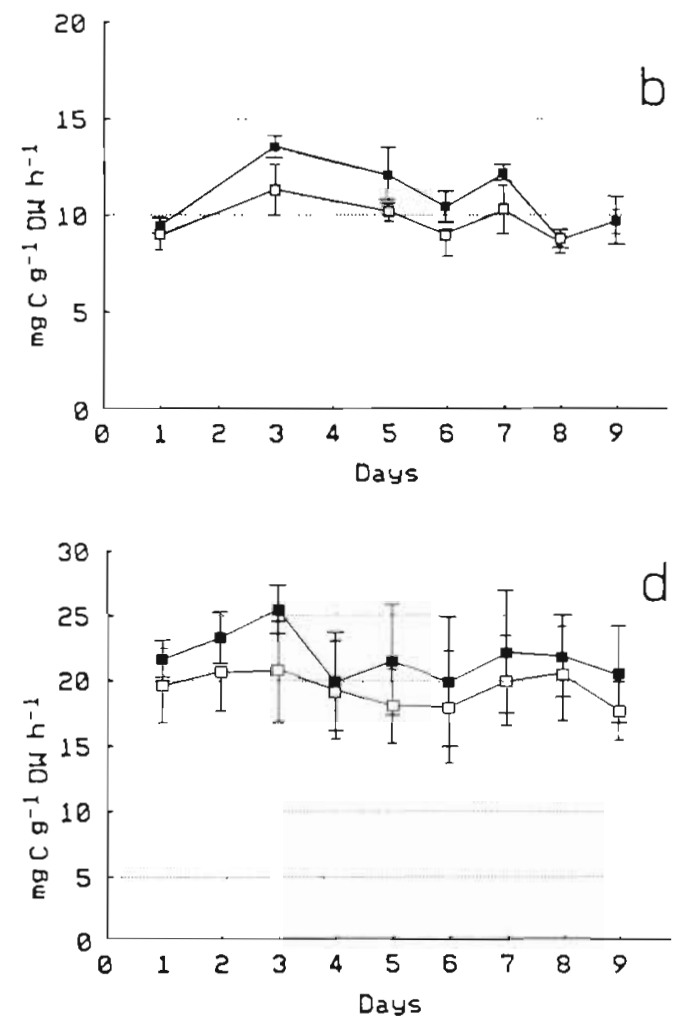

Fig. 1. Cystoseira barbata f. aurantia. Productivity curves without (a) and with ( $\square$ ) Caulerpa taxifolia in (a) winter, (b) spring, (c) summer, and (d) autumn. Error bars: standard deviation 

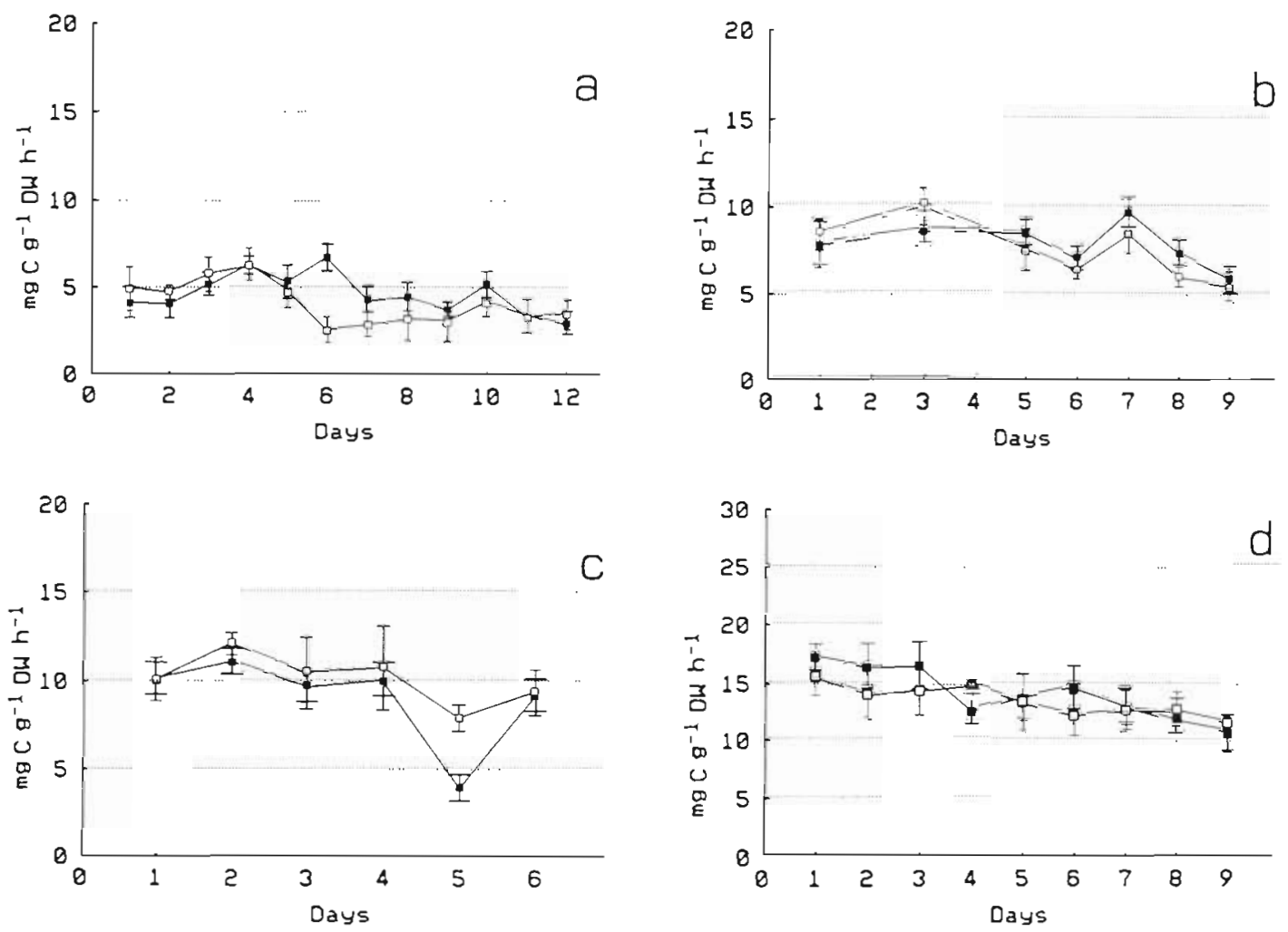

Fig. 2. Gracilaria bursa-pastoris. Productivity curves without (-) and with (a) Caulerpa taxifolıa in (a) winter, (b) spring, (c) summer, and (d) autumn. Error bars: standard deviation

in cultures with more than $125 \mathrm{\mu g} \mathrm{ml}^{-1}$ of extract, although some effects were noticed at lower concentrations (Fig. 3a). In Gracilaria bursa-pastoris, a significant decrease appeared at concentrations equal to or greater than $250 \mu \mathrm{g} \mathrm{ml}^{-1}$ only on the first and second days (Fig. 4a). In spring, the productivity of the specimens of C. barbata f. aurantia, $1 \mathrm{~d}$ after introducing the extract (Fig. 3b), was significantly reduced at concentrations equal to or greater than $30 \mu \mathrm{g} \mathrm{ml}^{-1}$. The productivity of $G$. bursa-pastoris was significantly lower at concentrations equal to or higher than $250 \mathrm{\mu g} \mathrm{ml}^{-1}$ (Fig. 4b). In summer, the significant reduction in the photosynthetic rate appeared at concentrations of between 5 and $10 \mu \mathrm{g} \mathrm{ml}^{-1}$ for C. barbata f. aurantia (Fig. 3c) and $15 \mu \mathrm{g} \mathrm{ml}^{-1}$ for G. bursa-pastoris (Fig. 4C); at higher concentrations the differences were much greater than in other seasons. Finally, in autumn the productivity of $C$. barbata f. aurantia and G. bursa-pastoris to the extracts became significantly lower at $5 \mu \mathrm{g}$ $\mathrm{ml}^{-1}$ (Figs. 3d \& 4d). Consequently, the maximum concentrations above which a significant reduction in productivity was observed were much lower in summer and autumn than during the other seasons of the year and $C$. barbata f. aurantia was more sensitive to the methanol extracts than G. bursa-pastoris.
Moreover, the effect of the extract ceased to be significant after 2 to $3 \mathrm{~d}$, although at high concentrations $\left(125,250\right.$ and $\left.500 \mathrm{\mu g} \mathrm{m}^{-1}\right)$ or in the seasons during which the influence was greatest it persisted until the end of the experiment. This decline in influence could be explained by the degradation of the caulerpenyne, which can take place after 24 or 48 h (Lemée pers. comm.). The toxicity of its degradation products remains to be established.

\section{DISCUSSION}

As mentioned in the 'Introduction', some algae, including the Caulerpales, synthesize toxic or repellent secondary metabolites as a strategy against herbivory and epiphytism (Lewis 1985, Paul \& Fenical 1987). In Caulerpa taxifolia caulerpenyne is the most abundant and the most active sesquiterpene (Lemée et al. 1993). Moreover, in the Mediterranean population, it is more abundant $(0.2 \%$ of fresh weight) than in the other tropical species of Caulerpa (Guerriero et al. 1992). Paul \& Fenical (1986) suggested that the diacetoxybutadiene group is responsible for the toxicity of caulerpenyne; this group is unknown in terrestrial nat- 


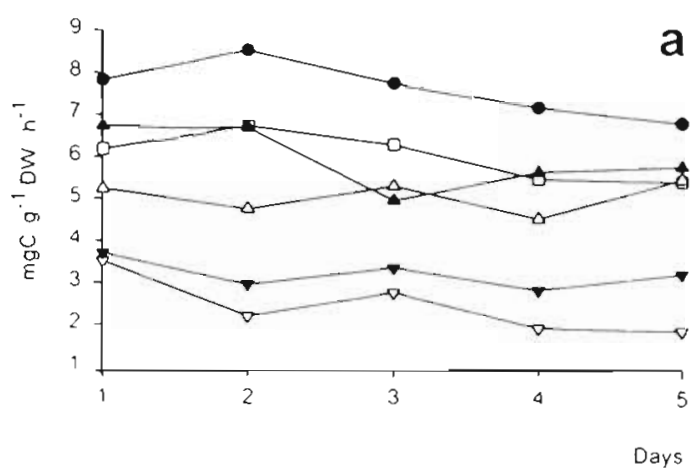

\begin{tabular}{|c|c|c|c|c|c|c|c|c|}
\hline \multirow[b]{2}{*}{ Days } & \multicolumn{8}{|c|}{ Caulerpa extracts $\left(\mu \mathrm{m} m l^{-1}\right)$} \\
\hline & 5 & 10 & 15 & 30 & 60 & 125 & 250 & 500 \\
\hline 1 & & & & $s$ & - & $S$ & $s$ & $s$ \\
\hline 2 & & & & - & . & $s$ & $s$ & $s$ \\
\hline 3 & & & & $s$ & $s$ & $\rightarrow$ & $s$ & 3 \\
\hline 4 & & & & - & - & s & $s$ & $s$ \\
\hline 5 & & & & $s$ & - & $S$ & $s$ & s \\
\hline
\end{tabular}

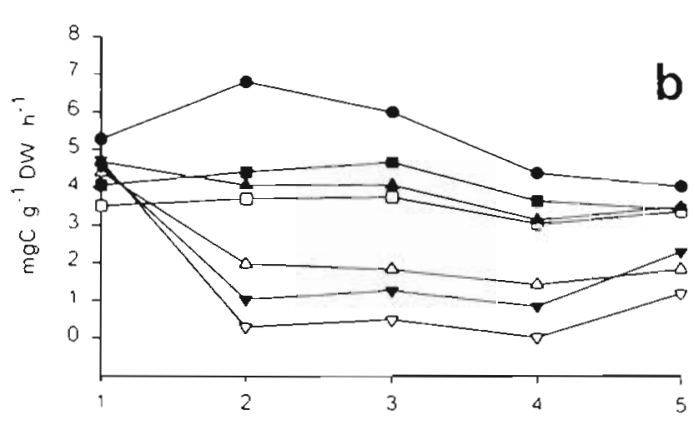

\begin{tabular}{|c|cccccccc|}
\hline & \multicolumn{7}{|l|}{ Caulerpa exuacis $\left(\mu \mathrm{g} \mathrm{m}^{-1}\right)$} \\
\hline Days & 5 & 10 & 15 & 30 & 60 & 125 & 250 & 500 \\
\hline 1 & & - & $\mathrm{S}$ & - & - & - & - \\
2 & & & $\mathrm{~S}$ & $\mathrm{~S}$ & $\mathrm{~S}$ & $\mathrm{~S}$ & $\mathrm{~S}$ \\
3 & & - & $\mathrm{S}$ & - & $\mathrm{S}$ & $\mathrm{S}$ & $\mathrm{S}$ \\
4 & & - & - & - & $\mathrm{S}$ & $\mathrm{S}$ & $\mathrm{S}$ \\
5 & & & - & - & - & $\mathrm{S}$ & $\mathrm{S}$ & $\mathrm{S}$ \\
\end{tabular}

Days

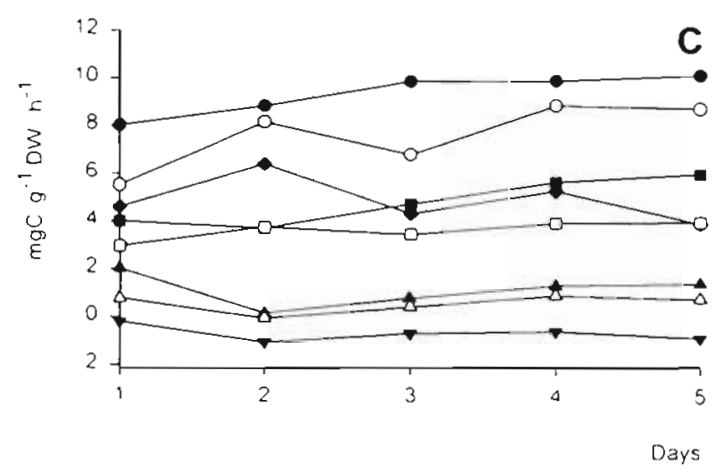

\begin{tabular}{|c|c|c|c|c|c|c|c|c|}
\hline \multirow[b]{2}{*}{ Days } & \multicolumn{8}{|c|}{ Caulerpa extracts $\left(\left.\mu \mathrm{g} m\right|^{-1}\right)$} \\
\hline & 5 & 10 & 15 & 30 & 60 & 125 & 250 & 500 \\
\hline 1 & $S$ & $S$ & $S$ & $S$ & $\$$ & $S$ & $S$ & \\
\hline 2 & - & $S$ & $S$ & $S$ & $s$ & $S$ & $S$ & \\
\hline 3 & - & - & $s$ & $S$ & $s$ & $S$ & $s$ & \\
\hline 4 & - & $\$$ & $\mathrm{~S}$ & $S$ & $S$ & $S$ & $s$ & \\
\hline 5 & - & - & $\mathrm{s}$ & $s$ & $s$ & $s$ & $\mathrm{~s}$ & \\
\hline
\end{tabular}

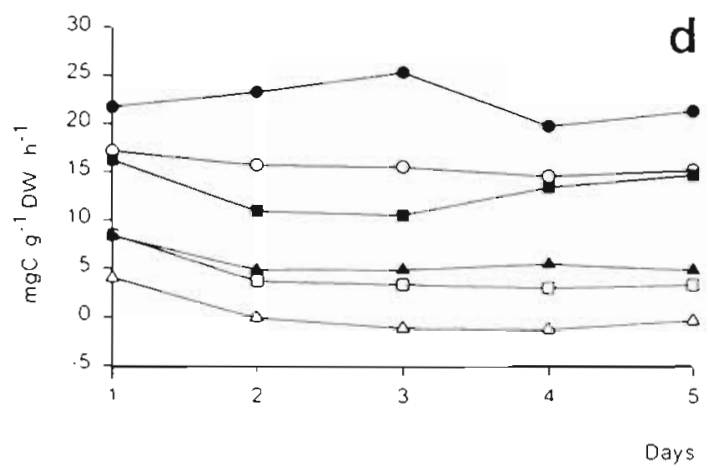

\begin{tabular}{|c|c|c|c|c|c|c|c|c|}
\hline \multirow[b]{2}{*}{ Days } & \multicolumn{8}{|c|}{ Caulerpa exiracts $\left.(\mu g m)^{-1}\right)$} \\
\hline & 5 & 10 & 15 & 30 & 60 & 125 & 250 & 500 \\
\hline 1 & $S$ & & $S$ & $S$ & $S$ & $S$ & & \\
\hline 2 & $s$ & & $s$ & $s$ & $s$ & $s$ & & \\
\hline 3 & $s$ & & $s$ & $s$ & $\rightarrow$ & $s$ & & \\
\hline 4 & $s$ & & 4 & $S$ & $s$ & $s$ & & \\
\hline 5 & s & & s & $s$ & $s$ & 5 & & \\
\hline
\end{tabular}

Fig. 3. Cystoseira barbata f. aurantia. Productivity curves with different concentrations of Caulerpa taxifolia extracts: $(\bullet) 0$, (0) 5 ,

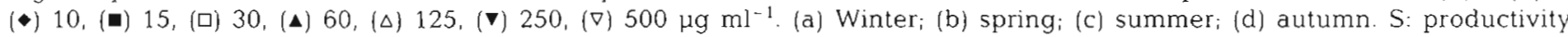
values significantly lower than control 


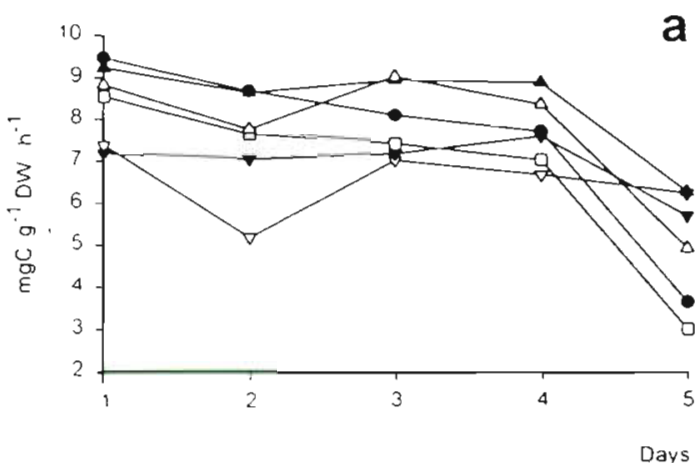

\begin{tabular}{|c|c|c|c|c|c|c|c|c|}
\hline \multirow[b]{2}{*}{ Days } & \multicolumn{8}{|c|}{ Caulerpa exuacis $\left(\mu \mu^{\prime} \cdot \mathrm{ml}^{-1}\right)$} \\
\hline & 5 & 10 & 15 & 30 & 60 & 125 & 250 & 500 \\
\hline 1 & & & & - & - & - & $s$ & $\mathrm{~S}$ \\
\hline 2 & & & & - & - & - & s & $S$ \\
\hline$i$ & & & & . & . & - & - & . \\
\hline 4 & & & & - & - & - & - & - \\
\hline 5 & & & & - & - & - & - & - \\
\hline
\end{tabular}

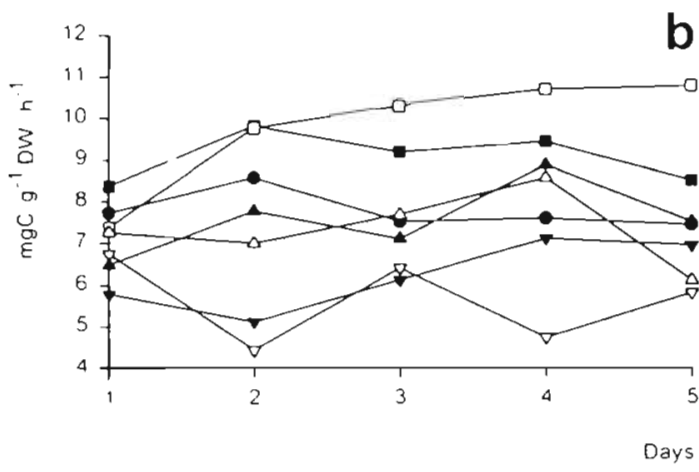

\begin{tabular}{|c|c|c|c|c|c|c|c|c|}
\hline \multirow[b]{2}{*}{ Days } & \multicolumn{8}{|c|}{ Caulerpa extracis $\left(\left.\mu \mathrm{g}^{\prime \prime \prime}\right|^{-1}\right)$} \\
\hline & 5 & 10 & 15 & 30 & 60 & 125 & 250 & 500 \\
\hline 1 & & & - & - & - & - & $s$ & - \\
\hline 2 & & & . & - & - & $s$ & $s$ & $S$ \\
\hline 3 & & & - & - & - & - & - & . \\
\hline 4 & & & - & - & - & - & - & $s$ \\
\hline 5 & & & - & - & - & - & - & $S$ \\
\hline
\end{tabular}

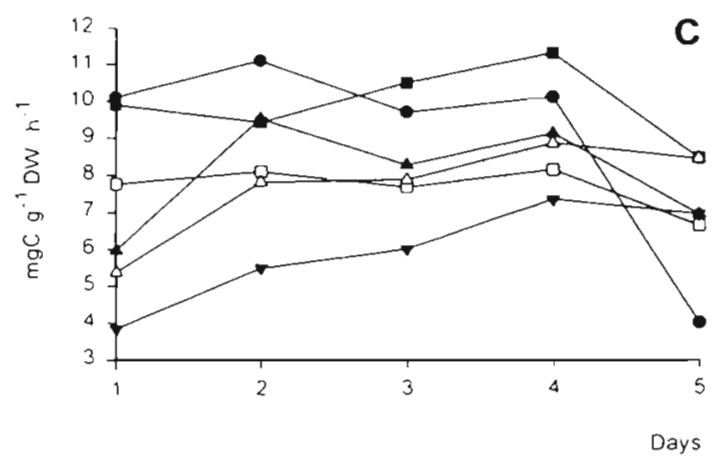

\begin{tabular}{|c|ccccclll|}
\hline \multicolumn{7}{|c|}{ Caulerpa extracls $\left(\mu \mathrm{m} \mathrm{mI}^{-1}\right)$} \\
\hline Days & 5 & 10 & 15 & 30 & 60 & 125 & 250 & 500 \\
\hline 1 & - & - & $S$ & 5 & $S$ & $S$ & $S$ & \\
2 & - & - & $S$ & $S$ & - & $S$ & $S$ & \\
3 & - & - & - & $S$ & - & $S$ & $S$ & \\
4 & - & - & - & $S$ & - & - & $S$ & \\
$\vdots$ & - & & - & - & - & - & - & \\
\end{tabular}

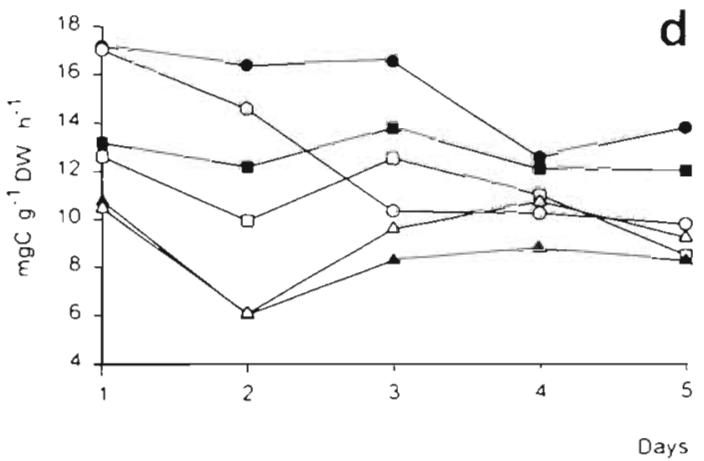

\begin{tabular}{|c|c|c|c|c|c|c|c|c|}
\hline & \multicolumn{8}{|c|}{ Caulerpa extracts $\left(\mu \mathrm{m} \mathrm{ml}^{-1}\right)$} \\
\hline Days & 5 & 10 & 15 & 30 & 60 & 125 & 250 & 500 \\
\hline 1 & - & & $S$ & $S$ & $S$ & $S$ & & \\
\hline 2 & - & & $s$ & $s$ & $s$ & $s$ & & \\
\hline ; & $s$ & & $s$ & $S$ & $S$ & $s$ & & \\
\hline 4 & $\Sigma$ & & - & . & $s$ & - & & \\
\hline 5 & s & & - & $S$ & $S$ & $S$ & & \\
\hline
\end{tabular}

Fig. 4. Gracilaria bursa-pastoris. Productivity curves with different concentrations of Caulerpa taxifolia extracts: $(\bullet) 0,(0) 5,(\bullet)$

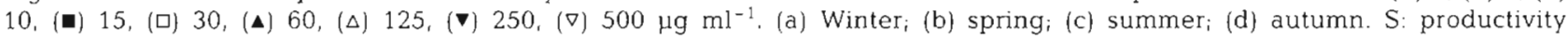
values significantly lower than control 
ural products, while it is characteristic of the Caulerpales (Paul \& Fenical 1987).

Little is known about the ecological role of the secondary metabolites synthesized by Caulerpa taxifolia in marine organisms that live close to it. In the Mediterranean some of its secondary metabolites are toxic to some organisms, such as sea urchin eggs, mammalian cells in culture and mice (Lemée et al. 1993). In the biotopes colonized by $C$. taxifolia, modifications have been observed in situ that suggest the diffusion of its toxic compounds in the surrounding water. For example, the presence of $C$. taxifolia affects the population structure of bacteria, increasing the proportion of Gram negative and reduction of the Gram positive bacteria (Giannotti et al. 1994). Moreover, in the leaves of Posidonia oceanica in fields colonized by C. taxifolia there is an increase in the level of phenolic compounds and a greater abundance of cells with tannins (Cuny et al. 1994), all of which are considered as plant defence. In addition, the presence of $C$. taxifolia inhibits the population growth of certain microalgae in vitro (Merino et al. 1994, 1995); this was most evident in summer, when all the species tested were affected (Merino et al. 1996). Furthermore, the metabolites released by $C$. taxifolia reduce the daily food intake of the sea urchin Paracentrotus lividus (Gobert 1992).

Our results show a negative effect of Caulerpa taxifolia, either due to direct contact or to contact. with its extracts, on the productivity of certain species of macroalgae.

The effect of Caulerpa taxifolia plants on the brown algae Cystoseira barbata f. aurantia is greater in spring and summer, and very weak in autumn. These results agree only partially with those of Lemée et al. (1993), who report maximum toxic effect in summer and autumn. The lack of agreement could be due to the fact that the maximal production of toxins by $C$. taxifolia does not necessarily coincide with the maximal release of them into the medium, since these processes depend on the biological cycle of this alga. In contrast, the absence of a chemical effect on Gracilaria bursa-pastoris suggests that certain marine macrophytes could possess mechanisms of resistance.

The presence of extracts of Caulerpa taxifolia in the cultures reduced the productivity of the algae tested, depending on the concentrations of the extracts. The impact of the extracts depended on the season, and was maximal in summer and autumn. The response of Gracilaria bursa-pastoris to the presence of extracts was, although positive, lower than that of Cystoseira barbata f. aurantia, in agreement with the results obtained in the preliminary experiments. For the same concentration of extract, for example $125 \mathrm{\mu g} \mathrm{ml}^{-1}$, the productivity of C. barbata f. aurantia was around $5 \mathrm{mg}$ $\mathrm{C} \mathrm{g}^{-1} \mathrm{DW} \mathrm{h}^{-1}$ in winter, had a value of 2 in spring, 1 in summer and reached negative values in autumn. These results agree with those obtained by Lemée et al. (1993), who reported maximum toxic effect of $C$. taxifolia in summer and autumn.

The seasonal variation in toxicity of Caulerpa taxifolia may reflect a seasonal variation of the biosynthesis of secondary metabolites. These variations are probably due to the different levels of concentration of caulerpenyne. Starting from the analyses carried out by $R$. Lemée on the samples used in our study, it was determined that the percentage of caulerpenyne of the corresponding extracts was lower than $0.2 \%$ in winter, $2.3 \pm 0.5 \%$ in spring, $7.7 \pm 0.5 \%$ in summer and $19 \pm 1 \%$ in autumn. Thus, following the above example, an extract with a concentration of $125 \mu \mathrm{g} \mathrm{ml}^{-1}$ presented a level of caulerpenyne of $0.25 \mu \mathrm{g} \mathrm{ml}^{-1}$ in winter, $2.87 \mu \mathrm{g}$ $\mathrm{ml}^{-1}$ in spring, $9.62 \mu \mathrm{g} \mathrm{ml} \mathrm{l}^{-1}$ in summer and $23.75 \mu \mathrm{g}$ $\mathrm{mi}^{-1}$ in autumn.

For their part, the productivity of the control specimens of Cystoseira barbata f. aurantia presented seasonal variations, which are related to their life cycle observed in situ, with 2 peaks of growth, one in spring and the other in autumn (Ferrer 1993). If the productivity curve of this taxon (maximum productivity in autumn) is compared with its response to the extracts (minimum productivity in autumn), it can be deduced that this productivity reduction is mainly related to the presence of toxins. Moreover, this reduction can increase since this species shows its maximum of activity in this season; in general organisms in active growth are more sensitive to toxins than when they are in a dormant phase.

Although the effect of the extracts was clearly shown by these experiments, the concentrations used were higher than those found in nature. To assess the impact of a dense population of Caulerpa taxifolia in nature it is necessary to be able to measure the concentrations of toxic metabolites dissolved in the water. It would also be interesting to discover the process of diffusion of these compounds in the water and to relate this to the life cycle of $C$. taxifolia. The results of our study with whole $C$. taxifolia specimens showed that impact was maximum in spring and summer, which conflicts with the maximum levels of caulerpenyne of this plant, but which did, however, agree with the maxima of growth and development of the natural populations of C. taxifolia. This suggests that the chemical effect of $C$. taxifolia in nature could be linked to their physiological state rather than to the maximum production levels of toxic metabolites. Moreover, necrosis and loss of fronds, which are difficult to reproduce in the laboratory, occur in C. taxifolia at the end of autumn and in winter. Future studies should attempt to analyze the concentration of these toxic metabolites or their degradation products, which are released during the loss of 
fronds. Taking into account that frond length is maximal in autumn (Meinesz et al. 1994a), as is the level of toxins, the diffusion of toxic compounds could also be very high at this time of the year.

In conclusion, although the success of the expansion of Caulerpa taxifolia in the Mediterranean is probably related to its greater competition for space and light, there is, in certain seasons of the year, a chemical action which inhibits the productivity of some species of autochthonous algae

Acknowledgements. We thank Charles François Boudouresque, Alex Meinesz, Rodolphe Lemée and Josep Hurtado who were kind enough to guide us on the Cap Martin dives and to lend us the material necessary for diving; Rodolphe Lemée and Philippe Amade who carried out the dosage of the caulerpenyne in our material: Enric Ballesteros and the anonymous reviewers for their comments and suggestions that improved this paper; Ester Clavero for her help in designing graphics. This work was completed with the support of the DG XI of the European Community and the DGICYT of the Spanish Ministry of Education and Science.

\section{LITERATURE CITED}

Amico $V$, Oriente $G$, Piatelli $M$, Trıngali $C$, Fatturusso $E$ Magno S, Mayol L (1978) Caulerpenyne, an unusual sesquiterpenoid from the green alga Caulerpa prolifera. Tetrahedron Lett 38:3593-3596

Boudouresque CF, Meinesz A, Verlaque A, Knoepffler-Péguy $M$ (1992) The expansion of the tropical alga Caulerpa taxifolia in the Mediterranean. Cryptog-Algol 13:144-145

Cuny P, Serve L, Jupin H, Boudouresque CF (1994) Les composés phénoliques hydrosolubles de Posidonia oceanica (phanérogame marine) dans une zone colonisée par la chlorophyte introduite Caulerpa taxifolia (Alpes maritimes, France, Méditerranée). In: Boudouresque $C F$, Meinesz A, Gravez $V$ (eds) First Intemational Workshop on Caulerpa taxifolia. GIS Posidonie publ, Marseille, p 355-364

Ferrer E (1.993) Contribució a l'estudi ecofisiològic de Cystoseira barbata f. aurantia (Kützing) Giaccone. Tesi de Llicenciatura, Universitat Autònoma Barcelona

Ferrer E, Gómez Garreta A, Ribera MA (1995a) Effet de Caulerpa taxifolia sur la productivité de deux macrophytes méditerranéennes. Rapp Comm Int Mer Médit 34:28

Ferrer E, Gómez Garreta A, Ribera MA (1996) Effect of Caulerpa taxifolia on two Mediterranean macrophytes. In: Ribera MA, Ballesteros E, Boudouresque CF. Gómez A Gravez $V$ (eds) Second International Workshop on Caulerpa taxifolia. Publicacions Universitat Barcelona, Barcelona, p 271-276

Ferrer E, Ribera MA, Gómez Garreta A (1995b) Effet des extralts de Caulerpa taxifolia sur la productivité de deux macrophytes méditerranéennes. Rapp Comm Int Mer Médit 34:28

Giannotti A, Ghelardi E, Senesi S (1994) Characterization of seawater bacterial communities within environments colonized by the tropical green seaweed Caulerpa taxifolia. In: Boudouresque, CF, Meinesz A, Gravez $V$ (eds) First International Workshop on Caulerpa taxifolia. GIS Posidonie publ, Marseille, p 197-201

Gobert J (1992) Effet de la diffusion des substances émises par Caulerpa taxifolia sur le comportement alimentaire de l'oursin Paracentrotus hvidus. Rapport de stage, Université de Paris

Guerriero A, Marchetti F, D'Ambrosio M, Senesi S, Dini F, Pietra F (1993) New ecotoxicologically and biogenetically relevant terpenes of the tropical green seaweed Caulerpa taxifolia which is invading the Mediterranean. Helv Chim Acta 76:855-864

Guerriero A, Meinesz A, D'Ambrosio M, Pietra F (1992) Isolation of toxic and potentially toxic sesqui- and monoterpens from the tropical green seaweed Caulerpa taxifolia which has invaded the region of Cap Martin and Monaco. Helv Chim Acta 75:689-695

Lemée $R$, Pesando $D$, Durand-Clement $M$, Dubreuil $A$, Meinesz A, Guerriero A, Pietra F (1993) Preliminary survey of toxicity of the green alga Caulerpa taxifolia introduced into the Mediterranean. $J$ Appl Phycol 5: $485-493$

Lewis SM (1985) Herbivory on coral reefs: algal susceptibility to herbivorous fishes. Oecologia 65:370-375

Littler MM (1979) The effects of bottle volume, thallus weight, oxygen saturation levels, and water movement on apparent photosynthetic rates in marine algae. Aquat Bot 7 21-34

Meinesz A, Benichou L, Blachier J, Komatsu T, Lemée R, Mari X (1994a) Note préliminajre sur les variations saisonnières de Caulerpa taxifolia en Méditerranée. In: Boudouresque CF, Meinesz A, Gravez V (eds) First International Workshop on Caulerpa taxifolia. GIS Posidonie publ, Marseille, p 285-290

Meinesz A, Hesse B (1991) Introduction et invasion de l'alque tropicale Caulerpa taxifolia en Méditerranée nord-occidentale. Oceanol Acta 14:415-426

Meinesz A, Vaugelas $J$ de, Cottalorda JM, Benichou $L$, Blachier J, Caye G. Chambet P, Delahaye L, Febvre M, Garin S, Komatsu T, Lemée R, Mari X, Molenaar H, Perney L, Pietkiewicz D (1994b) Suivi de l'invasion de l'algue tropicale Caulerpa taxifolia devant les côtes françaises de la Méditerranée. Situation au 31 décembre 1993. Rapport Laboratoire Environnement Marin Littoral, Université de Nice - Sophia Antipolis

Meinesz A, Vaugelas J de, Cottalorda JM, Caye G, Charrier S, Commeau T, Delahaye L, Febvre M, Jaffrenou F, Lemée R, Molenaar H, Pietkiewicz D (1995) Suivi de l'invasion de l'algue tropicale Caulerpá taxitolia devant les côtes françaises de la Méditerranée. Situation au 31 décembre 1994. Rapport Laboratoire Environnement Marin Littoral, Université de Nice Sophia - Antipolis

Merino V, Clavero E, Hernández-Mariné M (1994a) The effect of Caulerpa taxifolla (Vahl) C. Agardh on the growth of marine microalgae. In: Boudouresque $\mathrm{CF}$, Meinesz A, Gravez V (eds) First International Workshop on Caulerpa taxifolia. GiS Posidonie publ, Marseille, p 213-217

Merino V, Clavero E, Hernández-Mariné M (1.996) Seasonal variations in the effect of Caulerpa taxifolia (Vahl) $C$. Agardh on the growth of marine microalgae. In: Ribera MA, Ballesteros E, Boudouresque CF, Gómez A, Gravez V (eds) Second International Workshop on Caulerpa taxifolia. Publicacions Universitat Barcelona, Barcelona, $\mathrm{p}$ $265-270$

Merino V, Clavero E, Ribera MA, Hernández-Mariné M (1995) Seasonal effects of Caulerpa taxifolia (Vahl) C. Agardh on the growth of Phaeodactylum tricornutum Bohlin. Rapp Comm Int Mer Médit 34:36

Meyer KD, Paul VJ (1992) Intraplant variation in secondary metabolite concentration in three species of Caulerpa (Chlorophyta: Caulerpales) and its effects on herbivorous fishes. Mar Ecol Prog Ser 82:249-257 
Patterson GML, Norton TR, Furusawa E, Furusawa S, Kashiwagi M. Moore RE (1984) Antineoplastic evaluation of marine algal extracts. Bot Mar 27:485-488

Paul VJ, Fenical W (1986) Chemical defense in tropical green algae, order Caulerpales. Mar Ecol Prog Ser 34 $157-169$

Paul VJ, Fenical W (1987) Natural products chemistry and chemical defense in tropical marine algae of the phylum

This article was submitted to the editor
Chlorophyta. In: Scheuer PJ (ed) Bioorganic marine chemistry. Springer-Verlag. Berlin, p 1-29

Verlaque M. Fritayre P (1994) Incidence de l'algue introduite Caulerpa taxifolia sur le phytobenthos de Méditerranée occidentale. 2. Les peuplements d'algues photophiles de l'infralittoral. In: Boudouresque CF, Meinesz A, Gravez V (eds) First International Workshop on Caulerpa taxifolla GIS Posidonie publ, Marseille, p 349-353

Manuscript first received: July 23, 1996

Revised version accepted: January 27, 1997 